\title{
Correlation of antinuclear antibody and anti- double-stranded DNA antibody with clinical response to infliximab in patients with rheumatoid arthritis: a retrospective clinical study
}

Naoichiro Yukawa*, Takao Fujii, Seiko Kondo-Ishikawa, Hajime Yoshifuji, Daisuke Kawabata, Takaki Nojima, Koichiro Ohmura, Takashi Usui and Tsuneyo Mimori

\begin{abstract}
Introduction: The induction of antinuclear antibodies (ANAs) or anti-double-stranded (ds) -DNA antibodies (Abs) after infliximab (IFX) therapy in rheumatoid arthritis (RA) is a well-known phenomenon, but the correlation of such Abs with the clinical response to IFX has not yet been determined. The aims of this retrospective observational study were to examine the prevalence of positive ANA and anti-ds-DNA Abs before and after IFX therapy in patients with RA and to investigate whether an increased titer of such Abs is associated with the clinical efficacy of IFX.
\end{abstract}

Methods: One hundred eleven RA patients who had received IFX were studied. ANA (indirect immunofluorescence with HEp-2 cells) and anti-ds-DNA Abs (Farr assay) results were examined before and after IFX therapy.

Results: The overall clinical response assessed by EULAR response criteria was as follows: good response in 55\%, including remission in 38\%; moderate response in 18\%; and no response (NOR) in 27\%. The positivity of ANA ( $\geq 1: 160)$ and anti-ds-DNA Abs significantly increased from $25 \%$ to $40 \%(P=0.03)$ and from $3 \%$ to $26 \%(P<0.001)$ after IFX, respectively. EULAR response differed significantly according to the ANA titer before IFX $(P=0.001)$, and the efficacy of IFX became worse as the ANA titer before starting IFX increased. Furthermore, the differences in the clinical response of the ANA titer before IFX $\leq 1: 80$ and $\geq 1: 160$ were significant (good, moderate, and no response were $66 \%$, 9\%, and 25\% in $\leq 1: 80$ group versus $26 \%, 33 \%, 41 \%$ in $\geq 1: 160$ group, respectively; $P<0.001)$. In 13 patients whose ANA had increased after IFX, 10 showed NOR, only one showed a good response, and none reached remission. These clinical responses were significantly different from ANA no-change patients. In 21 patients with positive anti-ds-DNA Abs after IFX, 16 showed NOR, only two showed a good response, and none reached remission.

Conclusions: The present study suggests that the ANA titer before starting IFX predicts the clinical response to IFX. The increased titers of ANA or anti-ds-DNA Abs after IFX may be useful markers of NOR.

\section{Introduction}

Rheumatoid arthritis (RA) is a chronic, inflammatory disease with the potential to cause substantial joint damage and disability. Tumor necrosis factor (TNF)- $\alpha$ plays a central role in the pathogenesis of RA, as demonstrated by the clinical benefit of anti-TNF- $\alpha$

\footnotetext{
* Correspondence: naoichiy@kuhp.kyoto-u.ac.jp
Department of Rheumatology and Clinical Immunology, Graduate School of

* Correspondence: naoichiy@kuhp.kyoto-u.ac.jp
Department of Rheumatology and Clinical Immunology, Graduate School of Medicine, Kyoto University, 54 Shogoin Kawahara-cho, Sakyo-ku, Kyoto 6068507, Japan
}

therapy [1-6]. Infliximab (IFX), a chimeric anti-human TNF- $\alpha$ monoclonal antibody, has enabled great advances in the treatment strategy for RA, resulting in a paradigm shift of RA treatment. Although IFX therapy concomitant with methotrexate (MTX) is effective in the majority of RA patients, some patients have persistent active disease, and others lose efficacy after prolonged treatment [5-7]. However, no useful clinical marker has been established to predict such nonresponse (NOR) to IFX. 
The induction of antinuclear antibodies (ANAs) and anti-double stranded (ds)-DNA antibodies (Abs) during IFX therapy is a well-known phenomenon that has already been observed in earlier clinical trials [1-3]. It has been reported that the induction of ANAs is independent of the IFX dose $[2,8]$ and is not modified by concomitant treatment with MTX $[9,10]$, leflunomide, and corticosteroid [8]. Furthermore, the production of ANA is not associated with the clinical response to IFX [11], and even when the development of anti-ds-DNA Abs is observed, onset of lupus-like symptoms is extremely rare [12]. Thus, the significance of the development of such antibodies, including correlations of ANAs and anti-ds-DNA Abs with NOR in RA, has not yet been determined.

Recently, it was reported that the development of ANAs and anti-ds-DNA Abs with anti-TNF therapies may act as a marker of forthcoming treatment failure in patients with psoriasis [13]. Conversely, as in RA patients, it has been reported that ANAs are a predictive factor of infusion reactions during IFX as well as without MTX [14]. On the basis of these findings, the aims of this retrospective observational study were to examine the prevalence of positive ANAs and anti-ds-DNA Abs before and after IFX therapy in patients with RA, and to investigate whether the induction or increased titer of such Abs is associated with the clinical efficacy of IFX.

\section{Materials and methods}

\section{Patients and administration of infliximab}

One hundred eleven Japanese patients with RA, who had started using IFX as the first biologic agent from November 2003 to June 2009 in our hospital, were studied. All the patients had met the 1987 revised criteria of the American College of Rheumatology (ACR) for the classification of RA [15]. IFX concomitant with MTX was given at 0 (initial dose of $3 \mathrm{mg} / \mathrm{kg}$ ), 2, and 6 weeks, and then every 8 weeks. If the efficacy of IFX was insufficient, we were permitted to increase the dosage up to the full-bottled dose (for example, $150 \mathrm{mg}$ to $200 \mathrm{mg}$ in a patient weighing $50 \mathrm{~kg}$ ) or to shorten the administration interval up to every 6 weeks from 8 weeks, according to the judgment of the attending physician. Disease activity was assessed by the disease-activity score in 28 joints (DAS28 ESR) [16], and clinical responses to IFX were evaluated with the European League against Rheumatism (EULAR) response criteria [17]. In contrast to primary NOR patients who had never achieved moderate or good response, loss of response (LOR) was defined as DAS28 score returned to NOR according to the EULAR criteria, after having maintained moderate or good response during at least 3 times of administration of IFX. The present study was conducted in compliance with the Declaration of Helsinki and was approved by the Kyoto University Ethics Committee Review Board, and written informed consent was obtained from all patients.

\section{Determination of study point}

Determination of the study point after the IFX therapy is different in each group. In moderate- or goodresponse patients, the data were collected at a stable point after at least three consecutive administrations of IFX after an achievement of a moderate or good response. In LOR patients, the data were collected within 3 months after LOR was observed. In the IFX withdrawal group (including primary NOR patients), the data were collected just before IFX was discontinued. The intervals between before and after IFX were 6 to 286 weeks (mean, $87 \pm 57$ weeks), and the total number of IFX administrations was 3 to 38 times (mean, $13 \pm$ 7.3 times), respectively.

\section{Determination of antinuclear antibody and anti-ds-DNA antibody}

ANAs and anti-ds-DNA Abs were examined before and after IFX therapy. ANAs were determined by indirect immunofluorescence with HEp-2 cells, and anti-ds-DNA Abs by the Farr assay (normal, $<6 \mathrm{U} / \mathrm{ml}$ ).

\section{Statistical analysis}

Statistical analysis was performed with PAWS version 18 software, by using the Fisher Exact test for changes of ANAs and anti-ds-DNA Abs before and after therapy, the Jonckheere-Terpstra trend test for correlations between ANA titers and clinical response to IFX, and the $\chi^{2}$ test for comparison between two groups (including ANA $\leq 1: 80$ group versus $\geq 1: 160$ group, and ANA titers in the no-change group versus increased group after therapy, respectively), respectively. A value of $p<$ 0.05 was considered significant.

\section{Results}

Characteristics of the patients and clinical efficacy of IFX

The characteristics of $111 \mathrm{RA}$ patients are shown in Table 1: $82 \%$ were female patients; mean age was 51 years; and mean disease duration was 6.6 years at the baseline. Mean DAS28 before IFX was 5.37, and MTX was used in all patients at a mean dosage of $8.1 \mathrm{mg} /$ week. Corticosteroids were used in $61 \%$, and the mean dosage of prednisolone (PSL) was $6.2 \mathrm{mg} /$ day. At the study point, the total number of IFX administrations was 3 to 38 times (mean, 13 times). DAS28 had fallen to 3.55 from 5.37, and EULAR responses were as follows: good response in 55\%, including remission in $38 \%$; moderate response in $18 \%$; and NOR in $27 \%$, including LOR in $21 \%$, respectively. 
Table 1 Characteristics of 111 RA patients

\begin{tabular}{|c|c|}
\hline \multicolumn{2}{|l|}{ Baseline (before starting IFX) } \\
\hline Female, age (mean $\pm S D$, range) & $91 / 111(82 \%), 51.6 \pm 13.3$ years $(21 \sim 80)$ \\
\hline Disease duration (mean $\pm \mathrm{SD}$, range) & $6.6 \pm 6.4$ years ( 4 months $\sim 32$ years) \\
\hline DAS28 (ESR) (mean \pm SD, range) & $5.37 \pm 1.33(1.71 \sim 8.41)$ \\
\hline MTX (mean $\pm S D$, range) & (used in all the patients), $8.1 \pm 1.6 \mathrm{mg} /$ week $(4 \sim 14 \mathrm{mg})$ \\
\hline Corticosteroids users & $68 / 111$ patients $(61 \%)$ \\
\hline PSL dosage (mean $\pm S D$, range) & $6.2 \pm 3.2 \mathrm{mg} /$ day $(2 \sim 16 \mathrm{mg})$ \\
\hline \multicolumn{2}{|l|}{ At the study point } \\
\hline Total number of IFX (mean \pm SD, range) & $13.0 \pm 7.3$ times $(3 \sim 38)$ \\
\hline DAS28(ESR) (mean $\pm S D$, range) & $3.55 \pm 1.64(0.54 \sim 7.84)$ \\
\hline \multirow[t]{3}{*}{ EULAR response } & Good response 55\% (including remission 38\%) \\
\hline & Moderate response $18 \%$ \\
\hline & NOR 27\% (including LOR 21\%) \\
\hline Discontinuation & $45 / 111(41 \%)$ \\
\hline \multirow[t]{2}{*}{ Reasons for discontinuation } & Remission, eight; NOR, 21; adverse events, 14; \\
\hline & financial reasons, two \\
\hline
\end{tabular}

IFX, infliximab; LOR, loss of response; MTX, methotrexate; NOR, no response; PSL, prednisolone.

\section{Positivity of ANA and anti-ds-DNA Abs before and after therapy}

The prevalence of positive ANA $(\geq 1: 40)$ did not change before and after IFX (78\% to $82 \%$ ), but with ANA $\geq$ $1: 160$, the prevalence significantly increased from $25 \%$ to 40\% (Table 2; $P=0.03$, Fisher Exact test). Furthermore, the positivity of anti-ds-DNA Abs significantly increased from $3 \%$ to $26 \%(P<0.001$; Fisher Exact test). The changes of ANA titer between before and after IFX are shown in Figure 1.

\section{Correlation between ANA titer and clinical response to IFX}

Next, we studied the correlation between the ANA status before starting therapy with IFX and the clinical response to IFX. EULAR response (Figure 2(a), upper) and DAS28 after IFX (Figure 2(a), lower) were significantly different by ANA titer before starting IFX $(P=$ 0.001 and 0.002 , respectively, by the Jonckheere-Terpstra trend test), and the efficacy of IFX became worse if the ANA titer before IFX increased. No correlation was found between ANA titer before IFX and DAS28 before IFX (Figure 2(a), middle). In addition, clinical responses

Table 2 Positivity of ANAs and anti-DNA Abs before and after IFX

\begin{tabular}{lllll}
\hline & & Before IFX & After IFX & $\boldsymbol{P}_{\text {value }}{ }^{\mathbf{a}}$ \\
\hline ANA & $\geq 1: 40$ & $83 / 106$ & $77 / 94$ & NS \\
& & $78 \%$ & $82 \%$ & \\
\cline { 2 - 5 } & $\geq 1: 160$ & $27 / 106$ & $38 / 94$ & 0.03 \\
& & $25 \%$ & $40 \%$ & \\
\hline anti-DNA & $\geq 6 \mathrm{U} / \mathrm{ml}$ & $3 / 93$ & $21 / 80$ & $<0.001$ \\
& & $3 \%$ & $26 \%$ & \\
\hline
\end{tabular}

ANA, antinuclear antibodies; anti-DNAs, anti-ds-DNA antibodies; IFX, infliximab;

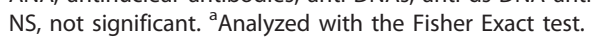

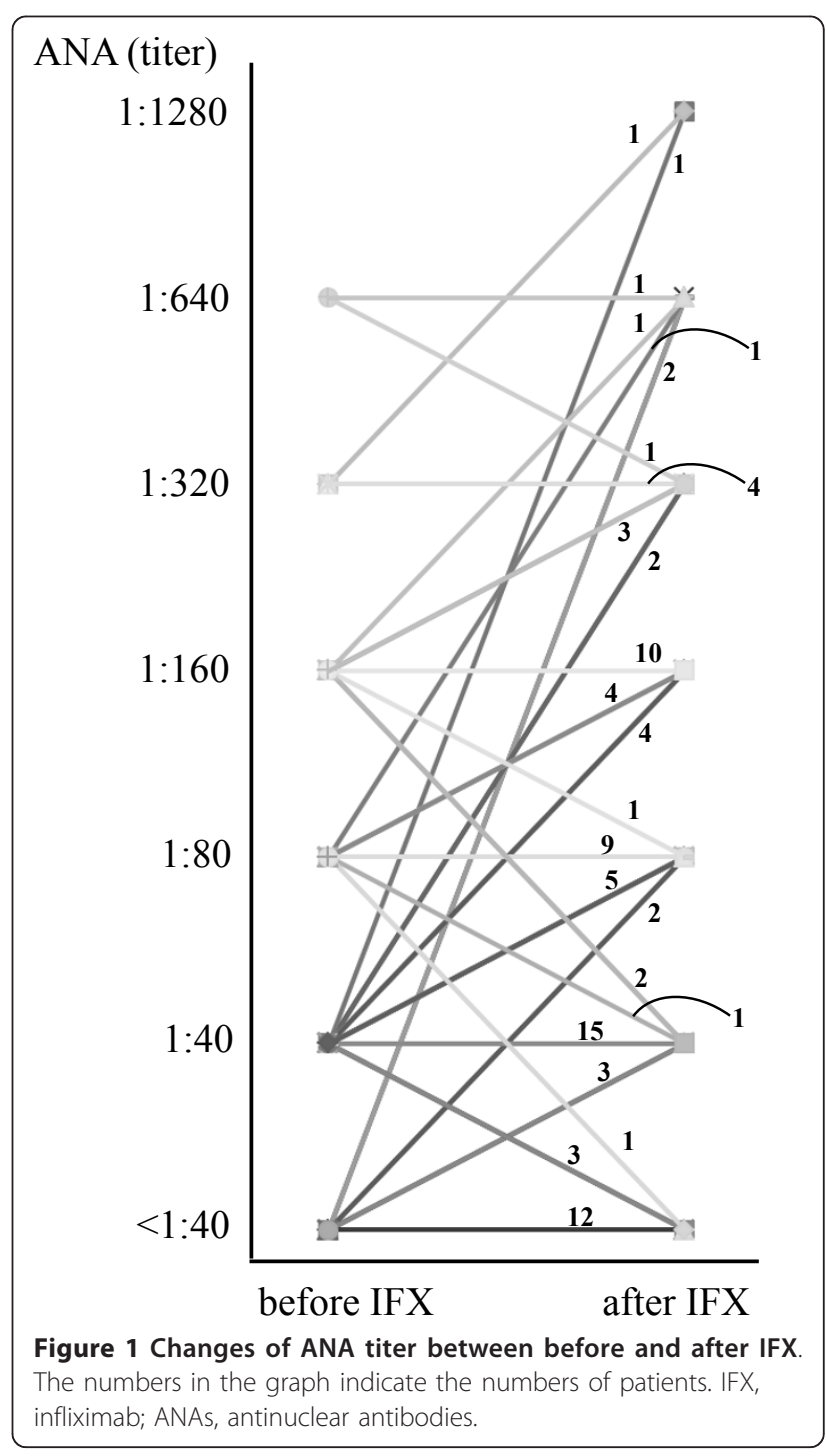



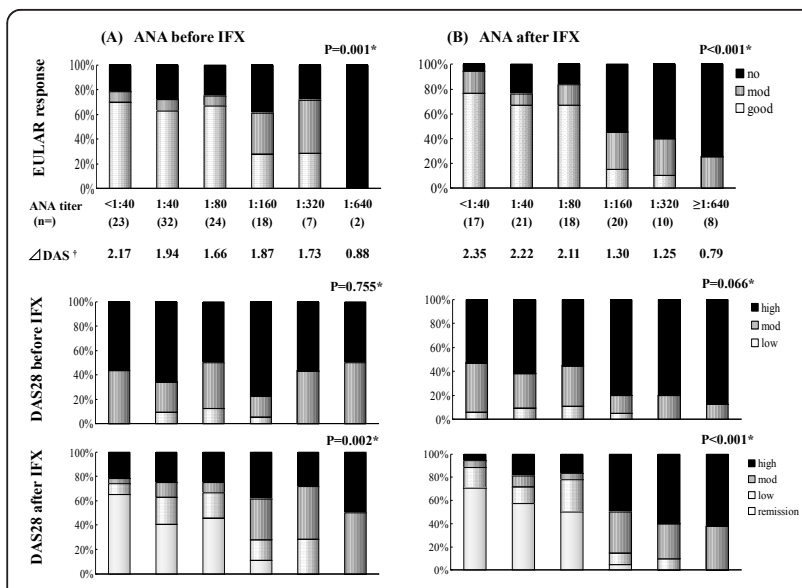

Figure $\mathbf{2}$ Correlation between ANA titer and clinical response to IFX. (a) Correlations between ANAs before starting therapy with IFX and clinical response to IFX. EULAR response (upper) and DAS28 after IFX (lower) were significantly different by ANA titer before IFX $(P=0.001$ and 0.002 , respectively, by Jonckheere-Terpstra trend test). The efficacy of IFX became worse as the ANA titer increased before starting IFX. (b) These clinical responses to IFX were analyzed with ANAs after starting IFX. The differences became more marked $(P<0.001$ in both EULAR response (upper) and DAS 28 after IFX (lower), by the Jonckheere-Terpstra trend test). ${ }^{*}$ Analyzed with the Jonckheere-Terpstra trend test. ${ }^{\dagger}$ Mean changes of DAS28 score before and after IFX.

seemed to be divided into two groups between the ANA titer before IFX with $\leq 1: 80$ and $\geq 1: 160$ in this figure. As shown in Table 3, the differences in the EULAR response between these two groups were significant $(P<$ $0.001, \chi^{2}$ test). Furthermore, when these clinical responses to IFX were analyzed by the ANA titers after starting IFX, such tendencies became more marked, as shown in Figure $1(\mathrm{~b})(P<0.001$ in both EULAR response (upper) and DAS 28 after IFX (lower), by the Jonckheere-Terpstra trend test). In the comparison of the ANA titer before IFX and the EULAR response, a significant difference in the ANA titer after IFX $\leq 1: 80$ and $\geq 1: 160$ was observed.

Table 3 Comparison of clinical response between ANA titer $\leq 1: 80$ and $\geq 1: 160$

\begin{tabular}{|c|c|c|c|c|c|c|}
\hline \multirow[b]{3}{*}{ EULAR } & \multicolumn{6}{|c|}{ ANA titer } \\
\hline & \multicolumn{3}{|c|}{ Before IFX } & \multicolumn{3}{|c|}{ After IFX } \\
\hline & $\leq 1: 80$ & $\geq 1: 160$ & $\begin{array}{l}P \\
\text { value }^{a}\end{array}$ & $\leq 1: 80$ & $\geq 1: 160$ & $\begin{array}{l}P \\
\text { value }^{a}\end{array}$ \\
\hline response & $\begin{array}{c}(n= \\
79)\end{array}$ & $\begin{array}{c}(n= \\
27)\end{array}$ & & $\begin{array}{c}(n= \\
56)\end{array}$ & $\begin{array}{c}(n= \\
38)\end{array}$ & \\
\hline Good & $66 \%$ & $26 \%$ & $<0.001$ & $77 \%$ & $11 \%$ & $<0.001$ \\
\hline (remission) & $(16 \%)$ & (7\%) & $<0.001$ & (59\%) & $(3 \%)$ & $<0.001$ \\
\hline Moderate & $9 \%$ & $33 \%$ & $<0.001$ & $7 \%$ & $29 \%$ & $<0.001$ \\
\hline No & $25 \%$ & $41 \%$ & $<0.001$ & $16 \%$ & $60 \%$ & $<0.001$ \\
\hline
\end{tabular}

ANA, antinuclear antibodies; IFX, infliximab; ${ }^{a}$ Analyzed with a $\chi^{2}$ test.
Clinical response of patients with increased ANA titer after IFX

Based on these results, we next examined patients whose ANAs had increased by two or more dilution levels (for example, ANA titer from $<1: 40$ to 1:80, from 1:80 to $1: 320$, and so on) after treatment with IFX (Table 4). Among these 13 patients, 10 showed NOR, only one showed a good response, and none reached remission. These clinical responses were significantly different from those of the ANA no-change patients (Table 5).

\section{Clinical response of patients with positive anti-ds-DNA antibodies after IFX}

The characteristics of 21 patients with positive anti-dsDNA antibodies after IFX are shown in Table 6. Sixteen of 21 patients showed NOR, only two showed a good response, and none reached remission. Interestingly, the second biologic agents, including other TNF antagonists switched from IFX, were all effective in these patients. Furthermore, three patients' clinical responses to IFX were restored by 20-mg PSL before each IFX infusion.

\section{Discussion}

In this study, we found that the high titer of ANAs ( $\geq$ $1: 160)$ significantly increased from $25 \%$ to $40 \%$ in RA patients after using IFX, and the positivity of anti-dsDNA Abs was also significantly increased from 3\% to $26 \%$. These results are similar to those of previous reports. Whereas the induction of ANAs and anti-dsDNA Abs during IFX therapy is a well-known phenomenon, the mechanisms of autoantibody production are poorly understood, and their clinical significance is

Table 4 Clinical response of the 13 patients with increased ANA titer after IFX

\begin{tabular}{cccc}
\hline & \multicolumn{2}{c}{ ANA titer } & EULAR response \\
\cline { 2 - 3 } 1 & Before & After & \\
\hline 2 & $<40$ & 80 & Good \\
3 & $<40$ & 80 & No \\
4 & $<40$ & 640 & No \\
5 & 40 & 640 & No \\
6 & 40 & 160 & No \\
7 & 40 & 160 & No \\
8 & 40 & 160 & Moderate \\
9 & 40 & 320 & No \\
10 & 40 & 320 & No \\
11 & 80 & 1,280 & No \\
12 & 160 & 640 & Moderate \\
13 & 320 & 640 & No \\
\hline
\end{tabular}

ANAs, antinuclear antibodies; IFX, infliximab. 
Table 5 Comparison of clinical response between ANA titer increased and no-change patients

\begin{tabular}{lccc}
\hline \multirow{2}{*}{$\begin{array}{l}\text { EULAR } \\
\text { response }\end{array}$} & \multicolumn{2}{c}{ ANA after IFX } & \\
\cline { 2 - 3 } & $\begin{array}{c}\text { Increased } \\
(\boldsymbol{n}=\mathbf{1 3})\end{array}$ & $\begin{array}{c}\text { No change } \\
(\boldsymbol{n}=\mathbf{7 6})\end{array}$ & $\boldsymbol{P}$ value $^{\mathrm{a}}$ \\
\hline Good & $8 \%$ & $54 \%$ & 0.001 \\
(Remission) & $(0)$ & $(42 \%)$ & 0.001 \\
Moderate & $15 \%$ & $20 \%$ & 0.001 \\
No & $77 \%$ & $26 \%$ & 0.001 \\
\hline
\end{tabular}

ANAs, antinuclear antibodies; IFX, infliximab.

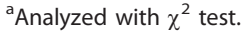

unknown. Several reasons for the production of ANAs and anti-ds-DNA Abs have been speculated on.

First, the direct effect of a decreased serum TNF level caused by a TNF blocker is considered. It has been reported that low levels of TNF- $\alpha$ may promote SLE in predisposed mice and that the treatment of (NZB/ NZW) $F_{1}$ mice with TNF- $\alpha$ ameliorates nephritis [18], and low TNF- $\alpha$ expression may be implicated also in human SLE patients [19]. Thus the blockade of TNF- $\alpha$ itself may favor a lupus-like autoimmunity phenomenon.

Second, anti-TNF treatment also reduces CRP levels, and CRP is known to help clear nuclear material after apoptosis. Low CRP levels would result in the prolonged exposure of nuclear material and hence further increase the chance of antibody formation [20,21]; however, serum CRP levels can be reduced not only by anti-TNF treatment but also by other antirheumatic drugs, including MTX and corticosteroids, and actually do not differ between patients with and without TNF blockade induced by autoantibodies [22]. Thus, these phenomena alone are not sufficient to explain the production of ANAs or anti-ds-DNA Abs. Moreover, because the reduction of serum TNF levels is caused by etanercept (ETN) and adalimumab (ADA), as well as IFX, it is difficult to explain the differences in the positivity of ANAs after treatment between IFX and ETN and the successful treatment of switching from IFX to ETN in patients with positive anti-ds-DNA Abs.

As already is known, IFX inhibits not only soluble TNF- $\alpha$ but also transmembrane TNF (tmTNF)- $\alpha$; the binding of IFX to tmTNF- $\alpha$ may provoke apoptotic cell death with the expression of autoantigens that could trigger the development of anti-ds-DNA antibodies [9]. In contrast, ETN binds mainly soluble TNF- $\alpha$; the ability of IFX to bind tmTNF- $\alpha$ may explain why IFX but not ETN induces the apoptosis of monocytes and T lymphocytes in Crohn disease [23]. A recent article demonstrated that all three anti-TNF drugs were able to bind tmTNF- $\alpha$ exposed by Jurkat cells, a human

Table 6 Twenty-one patients with positive anti-ds-DNA Abs after IFX

\begin{tabular}{|c|c|c|c|c|c|c|c|c|c|}
\hline & \multirow[b]{2}{*}{ age/sex } & \multicolumn{2}{|c|}{ anti-DNA } & \multicolumn{2}{|c|}{ ANA } & \multirow[b]{2}{*}{ EULAR response } & \multirow[b]{2}{*}{ symptoms } & \multirow[b]{2}{*}{ IFX } & \multirow[b]{2}{*}{ following biologics } \\
\hline & & before & after & before & after & & & & \\
\hline 1 & $51 / F$ & $<2$ & 300 & 40 & 320 & No & & Discontinue & $\mathrm{ADA}->\mathrm{TOC}^{* 4}$ \\
\hline 2 & $41 / F$ & 6 & 300 & 320 & 320 & No & & Discontinue & ETN \\
\hline 3 & $45 / F$ & 51 & 300 & 160 & 320 & No & SLE like ${ }^{* 1}$ & Discontinue & ETN \\
\hline 4 & $32 / F$ & NA & 52 & 320 & 1280 & No & & & \\
\hline 5 & $31 / F$ & 5 & 42 & 80 & 160 & No & SLE like ${ }^{* 2}$ & Discontinue & ETN \\
\hline 6 & $36 / F$ & 5 & 38 & 40 & 1280 & No- $>$ good & & PSL $20 \mathrm{mg} \mathrm{iv}^{* 3}$ & \\
\hline 7 & $43 / F$ & 4 & 26 & 160 & 640 & No & & Discontinue & TOC \\
\hline 8 & $56 / F$ & 3 & 26 & 80 & 160 & No- $>$ good & & PSL $20 \mathrm{mg}$ iv*3 & \\
\hline 9 & $62 / M$ & 21 & 25 & 80 & 80 & Good & PCP & Discontinue & TOC \\
\hline 10 & $65 / F$ & 2 & 23 & 160 & 160 & No & & Discontinue & $\mathrm{TOC}->\mathrm{ETN}^{* 5}$ \\
\hline 11 & $52 / \mathrm{F}$ & NA & 22 & NA & 160 & No & & & \\
\hline 12 & $56 / \mathrm{M}$ & $<2$ & 20 & 320 & 320 & No & allergy & Discontinue & ETN \\
\hline 13 & $33 / F$ & 5 & 19 & 40 & 80 & No & & & \\
\hline 14 & $51 / F$ & $<2$ & 13 & 40 & 80 & Mod & & & \\
\hline 15 & $56 / M$ & $<2$ & 11 & 160 & 160 & No- $>$ mod & & PSL $20 \mathrm{mg} \mathrm{iv}{ }^{* 3}$ & \\
\hline 16 & $75 / F$ & $<2$ & 11 & $<40$ & 320 & No & & Discontinue & ETN \\
\hline 17 & $58 / F$ & 11 & 11 & 80 & 640 & Mod & & & \\
\hline 18 & $30 / M$ & $<2$ & 10 & 80 & 80 & No & & Discontinue & ETN \\
\hline 19 & $35 / F$ & $<2$ & 10 & 80 & 80 & Good & & & \\
\hline 20 & $40 / F$ & 3 & 8 & 80 & 160 & No & & Discontinue & ETN \\
\hline 21 & $59 / F$ & NA & 7 & NA & 640 & Mod & & & \\
\hline
\end{tabular}

anti-DNA, anti-ds-DNA antibodies; ANA, antinuclear antibodies; IFX, infliximab; SLE, systemic lupus erythematosus; PCP; pneumocystis jirovecii pneumonia; PSL, prednisolone; iv, intravenous injection; ADA, adalimumab; ETN, etanercept; TOC, tocilizumab; *1, leukocytopenia and alopecia; *2, erythema; *3, premedication of each IFX administration; *4, ADA was also getting no response and successful swiched to TOC; ${ }^{*}$, TOC ineffective, and ETN effective 
lymphoblastoid cell line, and to induce similar antibodydependent cell-mediated cytotoxicity; in contrast, complement-dependent cytotoxicity was more pronounced with anti-TNF- $\alpha$ monoclonal antibodies in comparison with ETN [24]. These data suggest that ETN may be less effective than both IFX and ADA in the elimination of tmTNF- $\alpha$-expressing cells. The partially different mechanism of TNF- $\alpha$ inhibition between ETN and antiTNF- $\alpha$ monoclonal antibodies may explain the lesser generation of autoantibodies in patients treated with ETN in comparison with IFX, as well as the clinical efficacy of IFX and ADA but not of ETN in the treatment of granulomatous diseases such as Crohn disease and Wegener granulomatosis.

Thus, some reasonable explanations exist for the production of ANAs; however, it is unclear why their formation should be associated with the clinical response to IFX. Recently, it was shown that ANAs are a predictive factor of infusion reactions during IFX as well as without MTX in RA patients [14]. Furthermore, it was reported that the development of ANA and anti-ds-DNA Abs in anti-TNF therapies may act as a marker of forthcoming treatment failure in patients with psoriasis [13]. To our knowledge, the present study is the first report to clarify the correlation of ANAs and anti-ds-DNA Abs with the efficacy of IFX in RA patients. Moreover, surprisingly, the clinical response to IFX differed by the ANA titer before IFX, and the predictive value of the baseline ANA titer of $\leq 1: 80$ and $\geq 1: 160$ for the efficacy of IFX was observed. This result suggests that preexisting autoimmune abnormalities indicated by ANAs may influence the effect of IFX. Conversely, NOR of IFX was more markedly associated with the increase of ANAs or the induction of anti-ds-DNA Abs. Furthermore, in NOR patients, switching to second TNF antagonists and premedication of PSL without discontinuation of IFX were both effective, suggesting that IFX-induced autoimmune responses may affect the efficacy of IFX.

The mechanisms underlying treatment failure in RA patients treated with IFX have not been entirely clarified; however, one important factor may be the development of anti-drug antibody, or human anti-chimeric antibody (HACA) [1,2]. Because these antibodies cannot be routinely measured in the clinical setting, currently no clinically accessible markers of forthcoming treatment failure are available. Although HACA could not be determined in all patients in this study, we could measure serum HACA in three patients who were successfully restored from NOR by premedication with PSL without discontinuation of IFX, and HACA was negative, at least in these three patients.

Recently, Takeuchi et al. [7] reported that the clinical efficacy of IFX was correlated with the trough serum IFX level in a prospective randomized control trial (RISING study). The authors speculated that anti-IFX antibody may be an important factor influencing the efficacy of IFX by increasing the serum clearance of IFX; however, anti-IFX antibody and autoantibodies including ANAs were not measured in the RISING study. Although the IFX trough level was also not measured in our study, ANAs and antids-DNA Abs observed in the NOR patients in our study seemed to be indicators of the immunologic response to the decreased clinical efficacy of IFX. Recently, Hoffmann et al. [25] reported that ANAs and anti-ds-DNA Abs in psoriasis patients are predictors for LOR and anti-IFX antibody induction [25], and these data strongly supported our speculation. To confirm this speculation, a large-scale clinical study in RA patients is necessary to examine the correlations between the clinical efficacy of IFX and various factors, including the trough serum IFX level, antiIFX antibody, and autoantibodies (including ANAs and anti-ds-DNA Abs).

One important limitation of this study was that the approved dosage of IFX and MTX in Japan during the study period was only $3 \mathrm{mg}$

$\mathrm{kg}$ every 8 weeks (IFX) and $8 \mathrm{mg} /$ week (MTX), respectively. This approved dosage of IFX and MTX in Japan is much lower than that in Western countries, and it may result in insufficient clinical efficacy of IFX or suppression of immune responses to IFX. We therefore consider that it is necessary to research the production of ANAs and anti-ds-DNA Abs and their correlation with the clinical efficacy of IFX with a sufficient dosage of IFX and MTX.

Recently, several prognostic markers for the efficacy of IFX, including plasma platelet factor 4 [26] and the gene or mRNA profile in peripheral blood cells $[27,28]$, have been reported; however, the measurement of these markers is complicated and commercially unavailable, and the prognostic value remains insufficient. Regarding these points, ANA and anti-ds DNA Abs are routine laboratory tests and can be measured easily and simply in daily clinical practice. In addition, IFX is the only drug showing clinical evidence of the possibility of biologics-free remission and even drug-free remission $[29,30]$ among the several TNF antagonists, so it is necessary to establish prognostic markers of IFX efficacy, especially clinical remission.

\section{Conclusions}

The present study suggests that the ANA titer before starting IFX predicts the clinical response to IFX. Moreover, increased titers of ANAs or the development of anti-ds-DNA Abs after IFX may be useful markers of NOR. Large-scale prospective studies are required to assess the importance of this observation. 


\section{Abbreviations}

Abs: antibodies; ACR: American College of Rheumatology; ADA: adalimumab; ANAs: antinuclear antibodies; ds: double stranded; ETN: etanercept; EULAR: European League against Rheumatism; HACA: human anti-chimeric antibody; IFX: infliximab; LOR: loss of response; MTX: methotrexate; NOR: no response; PSL: prednisolone; RA: rheumatoid arthritis; SLE: systemic lupus erythematosus; TNF: tumor necrosis factor; tmTNF: transmembrane TNF.

\section{Acknowledgements}

This study was supported by a grant-in-aid for allergic and immunologic diseases from Ministry of Health, Labor and Welfare, Japan.

\section{Authors' contributions}

NY drafted the manuscript and performed the statistical analysis. NY and TF designed the study. NY, TF, SKI, HY, DK, TN, KO, TU, and TM collected the clinical data. NY, TF, HY, DK, TN, KO, TU, and TM enrolled patients for the study. TM supervised the study design and helped to draft the manuscript. All authors read and approved the final manuscript.

\section{Competing interests}

The authors declare that they have no competing interests.

Received: 23 June 2011 Revised: 25 November 2011

Accepted: 22 December 2011 Published: 22 December 2011

\section{References}

1. Maini RN, Breedveld FC, Kalden JR, Smolen JS, Davis D, Macfarlane JD, Antoni C, Leeb B, Elliott MJ, Woody JN, Schaible TF, Feldmann M: Therapeutic efficacy of multiple intravenous infusions of anti-tumor necrosis factor alpha monoclonal antibody combined with low-dose weekly methotrexate in rheumatoid arthritis. Arthritis Rheum 1998, 41:1552-1563.

2. Maini R, St Clair EW, Breedveld F, Furst D, Kalden J, Weisman M, Smolen J, Emery P, Harriman G, Feldmann M, Lipsky P, for the ATTRACT Study Group: Infliximab (chimeric anti-tumour necrosis factor alpha monoclonal antibody) versus placebo in rheumatoid arthritis patients receiving concomitant methotrexate: a randomised phase III trial: ATTRACT Study Group. Lancet 1999, 354:1932-1939.

3. Lipsky PE, van der Heijde DM, St Clair EW, Furst DE, Breedveld FC, Kalden JR, Smolen JS, Weisman M, Emery P, Feldmann M, Harriman GR, Maini RN, for the Anti-Tumor Necrosis Factor Trial in Rheumatoid Arthritis with Concomitant Therapy Study Group: Infliximab and methotrexate in the treatment of rheumatoid arthritis: Anti-Tumor Necrosis Factor Trial in Rheumatoid Arthritis with Concomitant Therapy Study Group. N Engl J Med 2000, 343:1594-1602.

4. St Clair EW, van der Heijde DM, Smolen JS, Maini RN, Bathon JM, Emery P, Keystone E, Schiff M, Kalden JR, Wang B, Dewoody K, Weiss R, Baker D, for the Active-Controlled Study of Patients Receiving Infliximab for the Treatment of Rheumatoid Arthritis of Early Onset Study Group: Combination of infliximab and methotrexate therapy for early rheumatoid arthritis: a randomized, controlled trial. Arthritis Rheum 2004 50:3432-3443.

5. Yamanaka H, Tanaka Y, Sekiguchi N, Inoue E, Saito K, Kameda H, likuni N, Nawata M, Amano K, Shinozaki M, Takeuchi T: Retrospective clinical study on the notable efficacy and related factors of infliximab therapy in a rheumatoid arthritis management group in Japan (RECONFIRM). Mod Rheumatol 2007, 17:28-32.

6. Tanaka Y, Takeuchi T, Inoue E, Saito K, Sekiguchi N, Sato E, Nawata M, Kameda H, Iwata S, Amano K, Yamanaka H: Retrospective clinical study on the notable efficacy and related factors of infliximab therapy in a rheumatoid arthritis management group in Japan: one-year clinical outcomes (RECONFIRM-2). Mod Rheumatol 2008, 18:146-152.

7. Takeuchi T, Miyasaka N, Inoue K, Abe T, Koike T: Impact of trough serum level on radiographic and clinical response to infliximab plus methotrexate in patients with rheumatoid arthritis: results from the RISING study. Mod Rheumatol 2009, 19:478-487.

8. Bacquet-Deschryver $H$, Jouen F, Quillard M, Ménard JF, Goëb V, Lequerré T, Mejjad O, Daragon A, Tron F, Le Loët X, Vittecoq O: Impact of three antiTNFalpha biologics on existing and emergent autoimmunity in rheumatoid arthritis and spondylarthropathy patients. I Clin Immunol 2008, 28:445-455.
9. Charles PJ, Smeenk RJ, De Jong J, Feldmann M, Maini RN: Assessment of antibodies to double-stranded DNA induced in rheumatoid arthritis patients following treatment with infliximab, a monoclonal antibody to tumor necrosis factor alpha: findings in open-label and randomized placebo-controlled trials. Arthritis Rheum 2000, 43:2383-2390.

10. Eriksson C, Engstrand S, Sundqvist KG, Rantapää-Dahlqvist S: Autoantibody formation in patients with rheumatoid arthritis treated with anti-TNF alpha. Ann Rheum Dis 2005, 64:403-407.

11. Allanore Y, Sellam J, Batteux F, Job Deslandre C, Weill B, Kahan A: Induction of autoantibodies in refractory rheumatoid arthritis treated by infliximab. Clin Exp Rheumatol 2004, 22:756-758.

12. De Bandt M, Sibilia J, Le Loët X, Prouzeau S, Fautrel B, Marcelli C, Boucquillard E, Siame JL, Mariette X, the Club Rhumatismes et Inflammation: Systemic lupus erythematosus induced by anti-tumour necrosis factor alpha therapy: a French national survey. Arthritis Res Ther 2005, 7:R545-551.

13. Pink AE, Fonia A, Allen MH, Smith CH, Barker JN: Antinuclear antibodies associate with loss of response to antitumour necrosis factor-alpha therapy in psoriasis: a retrospective, observational study. $\mathrm{Br} J$ Dermatol 2010, 162:780-785

14. Kapetanovic MC, Larsson L, Truedsson L, Sturfelt G, Saxne T, Geborek P: Predictors of infusion reactions during infliximab treatment in patients with arthritis. Arthritis Res Ther 2006, 8:R131.

15. Arnett FC, Edworthy SM, Bloch DA, McShane DJ, Fries JF, Cooper NS, Healey LA, Kaplan SR, Liang MH, Luthra HS, Medsger TA Jr, Mitchell DM, Neustadt DH, Pinals RS, Schaller JG, Sharp JT, Wilder RL, Hunder GG: The American Rheumatism Association 1987 revised criteria for the classification of rheumatoid arthritis. Arthritis Rheum 1988, 31:315-324.

16. Prevoo ML, van't Hof MA, Kuper HH, van Leeuwen MA, van de Putte LB, van Riel PL: Modified disease activity scores that include twenty-eightjoint counts: development and validation in a prospective longitudinal study of patients with rheumatoid arthritis. Arthritis Rheum 1995, 38:44-48.

17. van Riel PL, van Gestel AM, van de Putte LB: Development and validation of response criteria in rheumatoid arthritis: steps toward an international consensus on prognostic markers. Br J Rheumatol 1996, 35:4-7.

18. Jacob CO, McDevitt HO: Tumor necrosis factor-a in murine autoimmune 'lupus' nephritis. Nature 1988, 331:356-358.

19. Mitamura K, Kang H, Tomita Y, Hashimoto H, Sawada S, Horie T: Impaired tumour necrosis factor-alpha (TNF-alpha) production and abnormal B cell response to TNF-alpha in patients with systemic lupus erythematosus (SLE). Clin Exp Immunol 1991, 85:386-391.

20. Bickerstaff MC, Botto M, Hutchinson WL, Herbert J, Tennent GA, Bybee A, Mitchell DA, Cook HT, Butler PJ, Walport MJ, Pepys MB: Serum amyloid P component controls chromatin degradation and prevents antinuclear autoimmunity. Nat Med 1999, 5:694-697.

21. Gershov D, Kim S, Brot N, Elkon KB: C-Reactive protein binds to apoptotic cells, protects the cells from assembly of the terminal complement components, and sustains an antiinflammatory innate immune response: implications for systemic autoimmunity. J Exp Med 2000, 192:1353-1364.

22. De Rycke L, Baeten D, Kruithof E, Van den Bosch F, Veys EM, De Keyser F: Infliximab, but not etanercept, induces IgM anti-double-stranded DNA autoantibodies as main antinuclear reactivity: biologic and clinical implications in autoimmune arthritis. Arthritis Rheum 2005, 52:2192-2201.

23. Van den Brande JM, Braat $H$, van den Brink GR, Versteeg $H H$, Bauer $C A$, Hoedemaeker I, van Montfrans C, Hommes DW, Peppelenbosch MP, van Deventer SJ: Infliximab but not etanercept induces apoptosis in lamina propria T-lymphocytes from patients with Crohn's disease. Gastroenterology 2003, 124:1774-1785.

24. Mitoma H, Horiuchi T, Tsukamoto H, Tamimoto Y, Kimoto Y, Uchino A, To K Harashima S, Hatta N, Harada M: Mechanisms for cytotoxic effects of antitumor necrosis factor agents on transmembrane tumor necrosis factor alpha-expressing cells: comparison among infliximab, etanercept, and adalimumab. Arthritis Rheum 2008, 58:1248-1257.

25. Hoffmann JH, Hartmann M, Enk AH, Hadaschik EN: Autoantibodies in psoriasis as predictors for loss-of-response and anti-infliximab antibody induction. Br J Dermatol 2011, 165:1355-1358.

26. Trocmé C, Marotte H, Baillet A, Pallot-Prades B, Garin J, Grange L, Miossec P, Tebib J, Berger F, Nissen MJ, Juvin R, Morel F, Gaudin P: Apolipoprotein A-I 
and platelet factor 4 are biomarkers for infliximab response in rheumatoid arthritis. Ann Rheum Dis 2009, 68:1328-1333.

27. Lequerré $T$, Gauthier-Jauneau $A C$, Bansard $C$, Derambure $C$, Hiron M Vittecoq O, Daveau M, Mejjad O, Daragon A, Tron F, Le Loët X, Salier JP: Gene profiling in white blood cells predicts infliximab responsiveness in rheumatoid arthritis. Arthritis Res Ther 2006, 8:R105.

28. Sekiguchi N, Kawauchi S, Furuya T, Inaba N, Matsuda K, Ando S,

Ogasawara M, Aburatani H, Kameda H, Amano K, Abe T, Ito S, Takeuchi T: Messenger ribonucleic acid expression profile in peripheral blood cells from RA patients following treatment with an anti-TNF-alpha monoclonal antibody, infliximab. Rheumatology (Oxford) 2008, 47:780-788

29. Goekoop-Ruiterman YP, de Vries-Bouwstra JK, Allaart CF, van Zeben D, Kerstens PJ, Hazes JM, Zwinderman AH, Ronday HK, Han KH, Westedt ML, Gerards AH, van Groenendael JH, Lems WF, van Krugten MV, Breedveld FC, Dijkmans BA: Clinical and radiographic outcomes of four different treatment strategies in patients with early rheumatoid arthritis (the BeSt study): a randomized, controlled trial. Arthritis Rheum 2005, 52:3381-3390.

30. Tanaka Y, Takeuchi T, Mimori T, Saito K, Nawata M, Kameda H, Nojima T, Miyasaka N, Koike T, for the RRR study investigators: Discontinuation of infliximab after attaining low disease activity in patients with rheumatoid arthritis: RRR (remission induction by Remicade in RA) study. Ann Rheum Dis 2010, 69:1286-1291.

doi:10.1186/ar3546

Cite this article as: Yukawa et al:: Correlation of antinuclear antibody and anti-double-stranded DNA antibody with clinical response to infliximab in patients with rheumatoid arthritis: a retrospective clinical study. Arthritis Research \& Therapy 2011 13:R213.

\section{Submit your next manuscript to BioMed Central} and take full advantage of:

- Convenient online submission

- Thorough peer review

- No space constraints or color figure charges

- Immediate publication on acceptance

- Inclusion in PubMed, CAS, Scopus and Google Scholar

- Research which is freely available for redistribution

Submit your manuscript at www.biomedcentral.com/submit
Ciomed Central 